\title{
ВИВЧЕННЯ ЖОВЧОВИДІЛЬНО ТА ЖОВЧОУТВОРЮВАЛЬНО ФУНКЦІЙ ПЕЧІНКИ В УМОВАХ ТЕТРАХЛОРМЕТАНОВОГО ГЕПАТИТУ ПІСЛЯ ЗАСТОСУВАННЯ ЕКСТРАКТУ 3 ЛИСТЯ АБРИКОСА ЗВИЧАЙНОГО
}

\author{
๑А. Л. Штробля
}

\section{ДВНЗ «Ужгородський національний університет»}

РЕЗЮМЕ. В експерименті на щурах, уражених тетрахлорметаном, встановлені порушення у жовчовидільній та жовчоутворювальній функціях печінки. Це підтверджується зменшенням швидкості секреці жовчі та об'єму, а також зменшенням вмісту холестеролу та жовчних кислот у жовчі та збільшенням вмісту холестеролу у сироватці крові. Доведено позитивний вплив сухого екстракту з листя абрикоса звичайного на процеси жовчовиділення та жовчоутворення у щурів після ураження х тетрахлорметаном.

КЛЮЧОВІ СЛОВА: тетрахлорметан, сухий екстракт з листя аб рикоса звичайного, жовчовиділення, жовчоутворення.

Вступ. Згідно з даними МОЗ Укра ни за останні 20 років у всьому світі простежується чітка тенденція до росту захворювань печінки, що обумовлюють високу смертність населення. Не $є$ винятком і наша держава, де за останні роки відзначається суттєве підвищення численності людей із захворюваннями гепатобіліарно системи. Одне з перших місць серед них займають токсичні ураження печінки $[1,2]$.

Більшість уражень гепатобіліарно системи, незалежно від чинників, призводять до значних змін секреці жовчі, які поглиблюються за рахунок пошкодження дрібних жовчних ходів. Розлади жовчовидільно функці печінки супроводжуються деструктивними змінами клітинних мембран гепатоцитів [5].

При захворюваннях печінки та інших органів часто порушується не тільки зовнішньосекреторна функція, а й інші функці печінки, що негативно впливає на перебіг захворювання. У зв'язку з цим виникає потреба у використанні засобів, які стимулюють функці печінки - гепатопротекторів.

Сьогодні лікування рослинними засобами знову набуває популярності. Фітотерапія практично не має побічних ефектів і вважається більш «бережливою» для організму, ніж медикаментозне лікування. Помітний позитивний ефект при лікуванні фітопрепаратами з'являється повільніше, але зберігається довше. Відповідно, лікуватися за допомогою лікарських рослин потрібно довше, ніж за допомогою медикаментів $[4,7]$.

Враховуючи зацікавленість медиків до лікарських рослин, нашу увагу привернув сухий екстракт з листя абрикоса звичайного, який був досліджений на вміст БАР на кафедрі хімі природних сполук НфаУ [8].

Метою дано роботи було дослідження впливу сухого екстракту з листя абрикоса звичайного на процеси жовчовиділення та жовчоутворення у щурів, уражених тетрахлорметаном.

Матеріал та методи дослідження. Експерименти проводили на білих безпородних щурах масою тіла 180-200 г. Тварини були поділені на
4 групи: 1 - контрольні тварини; 2 - тварини, уражені тетрахлорметаном; 3 - уражені тетрахлорметаном тварини, яким протягом 4-х днів вводили сухий екстракт з листя абрикоса; 4 - щури, які після розвитку токсичного гепатиту 4 дні отримували алохол в дозі $80 \mathrm{Mг/кг.}$

Тетрахлорметан тварини отримували дворазово через день внутрішньочеревно у вигляді $50 \%$ олійного розчину в дозі 1,0 мл/кг маси тварини, згідно з методичними рекомендаціями ДФЦ МОЗ Укра ни [9].

Сухий екстракт з листя абрикоса звичайного тварини отримували щоденно внутрішньошлунково в дозі 70 мг/кг маси тіла.

Через 4 дні від останнього введення тетрахлорметану тварин оперували з використанням тіопенталу натрію та канюлювали жовчну протоку. Після забору жовчі проводили евтаназію щурів. Дослідженням піддавали жовч та сироватку крові, у яких вивчали вміст холестеролу та жовчних кислот [3].

Статистичну обробку отриманих даних проводили на ПК за допомогою програм «Microsoft Excel» та «STATISTICA 6,0» з розрахунком середніх величин, хніх похибок, критерію Стьюдента [6].

Зміни вважали достовірними при $\mathrm{p} \leq 0,05$.

Результати й обговорення. Тетрахлорметановий гепатит супроводжувався вираженим порушенням жовчовидільно функці печінки у щурів (табл. 1).

Після ураження щурів тетрахлорметаном швидкість секреці та об'єм жовчі у тварин вірогідно знижувались $(p<0,05)$, що може вказувати на порушення процесів утворення жовчі, пов'язаних з цитолітичним синдромом у печінці.

Використання екстракту з листя абрикоса звичайного призвело до відновлення жовчовидільно функці у щурів. Швидкість секреці жовчі у таких тварин становила 85 \% від рівня контрольно групи, що на $20 \%$ перевищувало рівень уражених щурів (65\%). Об'єм жовчі після застосування екстракту зазнав достовірного збільшення і сягнув рівня $90 \%$ від норми, тоді як в уражених він становив 75 \% (рис. 1). 
Оеляди літератури, ориаінальні дослідження, поеляд на проблему

Таблиця 1. Дослідження показників жовчовидільно функці на моделі ураження печінки тетрахлорметаном та після застосування коригуючих засобів ( $\mathrm{M} \pm \mathrm{m}, \mathrm{n}=6)$

\begin{tabular}{|c|c|c|c|c|}
\hline Показники & $\begin{array}{c}\text { Контрольні } \\
\text { тварини }\end{array}$ & $\begin{array}{c}\text { Уражені } \\
\text { тетрахлорметаном }\end{array}$ & $\begin{array}{c}\text { Уражені+ліковані } \\
\text { екстрактом, } \\
70 \mathrm{мг} / \mathrm{k}\end{array}$ & $\begin{array}{c}\text { Уражені }+ \\
\text { ліковані алохолом, } \\
80 \mathrm{Mг} / \mathrm{kr}\end{array}$ \\
\hline $\begin{array}{c}\text { Об'єм жовчі, } \\
\text { мл/100 г }\end{array}$ & $0,80 \pm 0,03$ & $0,60 \pm 0,03 *$ & $0,72 \pm 0,02 * *$ & $0,78 \pm 0,03 * *$ \\
\hline $\begin{array}{c}\text { Швидкість секреції } \\
\text { жовчі, мг/хв· } 100^{-1}\end{array}$ & $5,40 \pm 0,25$ & $3,50 \pm 0,17 *$ & $4,60 \pm 0,20 * *$ & $4,95 \pm 0,22 * *$ \\
\hline
\end{tabular}

Примітка. * - вірогідні відмінності між контрольними та ураженими тваринами $(p \leq 0,05)$; ** вірогідні відмінності між ураженими та лікованими тваринами $(p \leq 0,05)$.

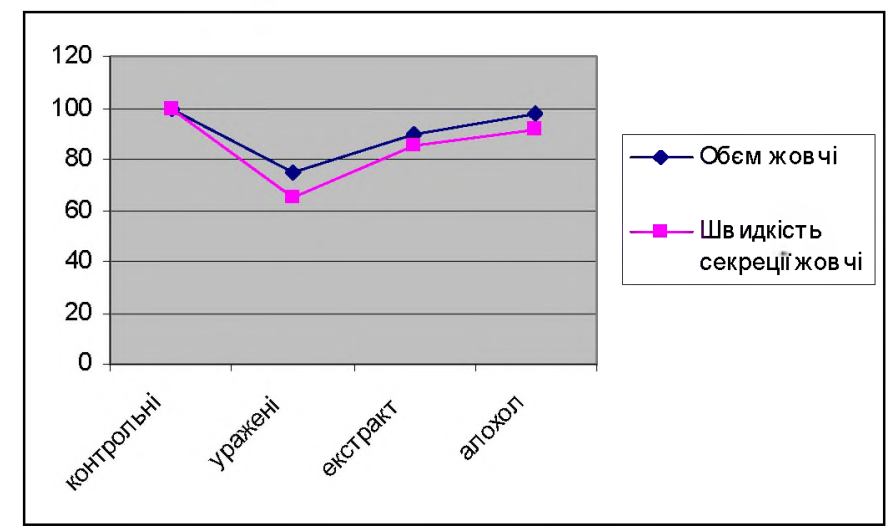

Рис. 1. Швидкість секреці та об'єм жовчі у щурів, уражених тетрахлорметаном та після застосування коригуючих чинників, \%.

Алохол виявився більш ефективним, після його застосування об'єм жовчі був на рівні інтактного контролю, швидкість секреці лише на $8 \%$ відрізнялася від норми.

Відомо, що холестерол $\epsilon$ попередником жовчних кислот - фізіологічних регуляторів зовнішньосекреторно функці печінки. Порушення обміну холестеролу і утворення ЖК, поряд із зниженням транспортно здатності мембран гепатоцитів, вважають важливими причинами порушення процесів жовчоутворення і жовчовиділення.

Нами досліджено вміст холестеролу в жовчі та сироватці крові щурів, уражених тетрахлорметаном, та після застосування сухого екстракту з листя абрикоса та алохолу (табл. 2).

Таблиця 2. Вміст холестеролу та жовчних кислот у сироватці крові та жовчі щурів, уражених тетрахлоретаном, та після застосування лікарських засобів $(\mathrm{M} \pm \mathrm{m}, \mathrm{n}=6)$

\begin{tabular}{|c|c|c|c|c|}
\hline Показники & $\begin{array}{c}\text { Контрольні } \\
\text { тварини }\end{array}$ & $\begin{array}{c}\text { Уражені } \\
\text { тетрахлорметаном }\end{array}$ & $\begin{array}{c}\text { Уражені+ліковані } \\
\text { екстрактом, } \\
70 \text { мг/кг }\end{array}$ & $\begin{array}{c}\text { Уражені }+ \\
\text { ліковані алохолом, } \\
80 \text { мг/кг }\end{array}$ \\
\hline $\begin{array}{c}\text { Холестерол у жовчі, } \\
\text { мг/100 мл }\end{array}$ & $45,30 \pm 2,15$ & $35,20 \pm 2,50^{*}$ & $39,40 \pm 3,20$ & $42,50 \pm 3,10$ \\
\hline $\begin{array}{c}\text { Жовчні кислоти у жовчі, } \\
\text { мг/100 мл }\end{array}$ & $798,40 \pm 32,50$ & $720,60 \pm 32,20$ & $764,50 \pm 35,40$ & $782,50 \pm 31,50$ \\
\hline $\begin{array}{c}\text { Холестерол у сироватці } \\
\text { крові, ммоль/л }\end{array}$ & $2,25 \pm 0,12$ & $3,65 \pm 0,16^{*}$ & $2,82 \pm 0,11^{* *}$ & $2,45 \pm 0,12 * *$ \\
\hline
\end{tabular}

Примітка. * - вірогідні відмінності між контрольними та ураженими тваринами (p $\leq, 05)$; ** - вірогідні відмінності між ураженими та лікованими тваринами $(\mathrm{p} \leq 0,05)$.

Через 4 доби після ураження в жовчі тварин відмічалось достовірне зниження вмісту холестеролу $(p<0,05)$, яке становило 78 \% від рівня контролю. У сироватці крові даний показник у цей же термін дослідження на $62 \%$ перевищив рівень норми. Гіперхолестеринемія на тлі зниження вмісту холестеролу у жовчі свідчить про розвиток синдрому холестазу в ураженому організмі.

Застосування сухого екстракту з листя абрикоса звичайного проявило ефективний вплив на процеси жовчоутворення, зокрема на вміст холестеролу, який у сироватці крові виявився на $37 \%$ 
Оеляди літератури, оригінальні дослідження, поеляд на проблему

меншим, ніж в уражених тварин, у жовчі на $9 \%$ зріс, у порівнянні з цими ж щурами.

При вивченні вмісту жовчних кислот у жовчі достовірних змін не спостерігалось після ураження тварин (вміст жовчних кислот зменшився на $10 \%$ ), після застосування досліджуваного екстракту він становив $96 \%$ від рівня норми, після застосування алохолу - $98 \%$.

\section{ЛІТЕРАТУРА}

1. Богомолов П. О. Коррекция печеночной энцефалопатии: патофизиологические основы применения пребиотиков / П. О. Богомолов, А. В. Петраков, О. С. Кузьмина // Трудный пациент. - 2006. - № 7. - С. 37-40.

2.Болезни печени и желчевыводящих путей : [под ред. Ивашкина В. Т.]. - М. : М-Вести, 2002. - 416 с.

3. Гонський Я. І. Біологічна хімія : лабораторний практикум / Я. І. Гонський, Н. П. Саюк, Л. М. Рубіна [та ін.] ; під ред. Я. І. Гонського. - Тернопіль : Укрмедкнига, 2001. - 288 с.

4. Доркина Е. Г. Изучение гепатозащитного действия природных флавоноидных соединений / Е. Г. Доркина // Экспериментальная клиническая фармакология. 2004. - Т. 67, № 6. - С. 41-44.

5. Иванченкова Р. А. Хронические заболевания желчевыводящих путей / Р. А. Иванченкова. - М. : Атмосфера, 2006. $-416 \mathrm{c}$.
Висновки. Ураження тварин тетрахлорметаном призводить до порушення процесів жовчовиділення та жовчоутворення в організмі. Сухий екстракт з листя абрикоса звичайного проявляє коригуючий вплив на дані процеси, що може бути підтвердженням прояву гепатопротекторно активності дано лікарсько форми.

\title{
RESEARCH OF BILE EXCRETION AND BILE FORMATION FUNCTIONS OF LIVER UNDER CONDITIONS OF TETRACHLOROMETHANE HEPATITIS AFTER USE OF THE APRICOT LEAVES EXTRACT
}

6. Лапач С. Н. Статистические методы в медико-биологических исследованиях с использованием Excel/ С. Н. Лапач, А. В. Чубенко, П. Н. Бабич. - К. : Морион, 2000. $-320 \mathrm{c}$.

7. Вивчення гепатопротекторно активності флавонів, флавонолів і флаванонів на моделі гострого ураження печінки тетрахлорметаном / С. В. Місюрьова, І. А. Зупанець, І. О. Журавель [та ін.] // Вісн. фармаці . - 2004. № 3. - C. 66-71.

8. Пузак О. А. Фармакогностичне вивчення сировини Armeniaca Vulgaris Lam. : автореф. дис. канд. фарм. наук / О. А. Пузак. - Харків, 2012. - 20 с.

9. Стефанов А. В. Доклинические испьтания лекарственных средств. Методические рекомендации : под. ред. чл.-кор. АМН Украины А. В. Стефанова. - К. : Авиценна, 2002. $-568 \mathrm{c}$.

CA. L. Shtroblia

\author{
SHEI «Uzhhorod National University»
}

SUMMARY. In the experiment with rats infected with tetrachloromethane the bile excretion and bile formation dysfunctions were determined. It is confirmed by the decrease in the rate of bile secretion and its volume, as well as the decrease of the cholesterol content and bile acids in bile and the increase of cholesterol content in blood serum. A positive effect of the dry extract of the apricot leaves on the bile excretion and bile formation processes in rats after tetrachloromethane damage was proved.

KEY WORDS: tetrachloromethane, dry extract of the apricot leaves, bile excretion, bile formation.

Отримано 17.03 .2015 